\section{$-3$}

$3 / 20 / \frac{105}{10}$

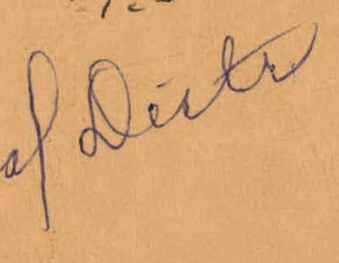

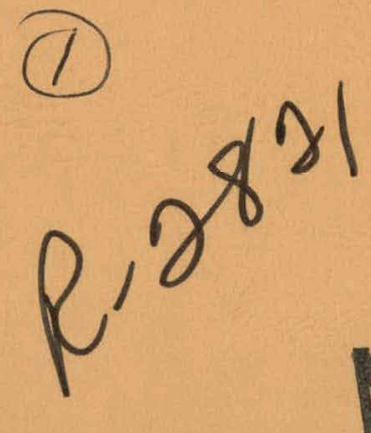

W A PD-TM-1443 DOE RESEARCH AND DEVELOPMENT REPORT

FISSION GAS RELEASE FROM OXIDE FUELS AT HIGH BURNUPS

(AWBA Development Program)

FEBRUARY 1981

CONTRACT DE-AC11-76PNOOO14

BETTIS ATOMIC POWER LABORATORY WEST MIFFLIN, PENNSYLVANIA

Operated for the U. S. Department of Energy by

WESTINGHOUSE ELECTRIC CORPORATION 


\section{DISCLAIMER}

This report was prepared as an account of work sponsored by an agency of the United States Government. Neither the United States Government nor any agency Thereof, nor any of their employees, makes any warranty, express or implied, or assumes any legal liability or responsibility for the accuracy, completeness, or usefulness of any information, apparatus, product, or process disclosed, or represents that its use would not infringe privately owned rights. Reference herein to any specific commercial product, process, or service by trade name, trademark, manufacturer, or otherwise does not necessarily constitute or imply its endorsement, recommendation, or favoring by the United States Government or any agency thereof. The views and opinions of authors expressed herein do not necessarily state or reflect those of the United States Government or any agency thereof. 


\section{DISCLAIMER}

Portions of this document may be illegible in electronic image products. Images are produced from the best available original document. 


\title{
FISSION GAS RELEASE FROM OXIDE FUELS AT HIGH BURNUPS
}

(AWBA DEVELOPMEIVT PROGRAM).

\author{
C. C. Dollins \\ Contract DE-AC11-76PNO0014 \\ February 1981 \\ Printed in the United States of America \\ Available from the \\ National Technical Information Service \\ U. S. Department of Commerce \\ 5285 Port Royal Road \\ Springfield, Virginia 22151
}

NOTE

This document is an interim memorandum prepared primarily for intermal reference and does not represent a final expression of the opinion of Westinghouse. When this memorandum is distributed extermally, it is with the express understanding that Westinghouse makes no representation as to completeness, accuracy, or uoability of information contained therein.

Operated for the U. S. Department of Energy by WESTINGHOUSE ELECTRIC CORPORATION

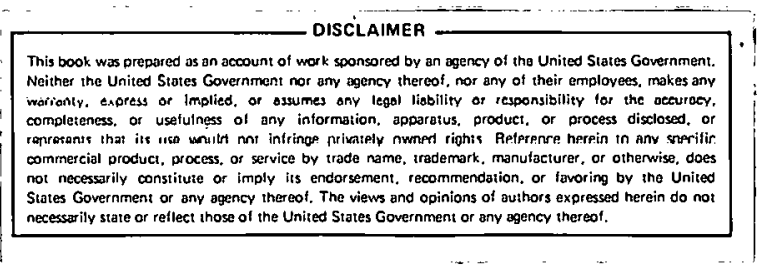


NOTICE

This report was prepared as an account of work sponsored by the United States Government. Neither the United States, nor the United States Department of Energy, nor any of their employees, nor any of their contractors, subcontractors, or their employees, makes any warranty, express or implied, or assumes any legal liablitty or responsibility for the accuracy, completeness or usefulness of any information, apparatus, product or process disclosed, or represents that its use would not infringe privately owned rights. 
The Shippingport Atonic Power Station located in Snippingport, Pennsylvania was the first large-scale, central-station nuclear puwer plant in the United States and the first plant of such size in the world operated solely to produce electric power. This program was started in 1953 to confinm the practical application of nucleär power for large-scale electric power generation. It has provided much of the technology being used for design and operation of the commericial, central-station nuclear power plants now in use.

Subsequent to develupment and successful operation of the Pressurized Water Reactor in the Atomic Energy Commission (now Departinent of Energy, DOE) owned reactor plant at the Shippingport Atonic Power Station, the Atonic Energy Commission in 1965 undertook a research and development prograin to design and build a Light Water Breeder Reactor core for operation in the Shippingport Station.

The objective of the Light Water Breeder Reactor (LWBR) prograin has been to develop a technology that would significantly improve the utilization of the nation's nuclear fuel resources employing the well-establi shed water reactor technology. To achieve this objective, work has been directed toward analysis, design, component tests, and fabrication of a water-cooled, thorium oxide-uraniuin oxide fuel cycle breeder reactor for installation and operation at the Shippingport Station. The LWBR core started operation in the Shippingport Station in the Fall of 1977 and is expected to be operated for about 4 to 5 years or more. At the end of this period, the core will be removed and the spent fuel shipped to the Naval Reactors Expended Core Facility for a detailed examination to verify core performance including an evaluation of breeding characteristics.

In 1976, with fabrication of $t$ Shippingport LWBR core nearing completion, the Energy Research and Development Adninistration, now DOE, established the Advanced Water Breeder Application (AWBA) program to develop and disseminate technical infonnation which would assist U.S. industry in evaluating the HBR concept for commercial-scale application. The program is exploring sone bf the problems that would be faced by industry in adapting technology confinied : in the LWBR program. Information being developed includes concepts for commercial-scale prebreeder cores which would produce uranium-233 tor. 11 gifis: water breeder cores while producing electric power, improvements for breeder: cores based on the technology developed to fabricate and operate the Shippingport LWBR core, and other information and technology to aid in evaluating commercial-scale application of the LWBR concept.

All three devel opment prograns (Pressurized Water Reactor, Light Water Breeder. Reactor, and Advanced Water Breeder Applications) are under the technical direction of the Office of the Deputy Assistant Secretary for Naval Reactors of DOE. They have the goal of developing practical improvements in the utilization of nuclear fuel resources for generation of electrical eneigy. using water-cooled nuclear reactors.

Technical information developed under the Shippingport, LWBR, and AWBA programs has been and will continue to be published in technical memoranda, one of which is this present report. 
WAPD-TM-1443

TABLE OF CONTENTS

TITLE

PAGE

Introduction

1

Theory

2

Data Comparisons

3

Summary and Conclusions

4

References

6 
ABSTRACT

Fission Gas Release from Oxide Fuels at High Burnups

(AWBA Development Program)

c. C. Dollins

The steady state gas release, swelling and densification model previously developed for oxide fuels has boen modified to accommodate the slow transients in temperature, temperature gradient, fission rate and pressure that are encountered in normal reactor operation. The gas release predictions made by the model were then compared to gas release data on LMFBR-EBRII fuels obtained by Dutt and Baker and reported by Meyer, Beyer, and Voglewede. Good agreement between the model and the data was found. A comparison between the model and three other sets of gas release data is also shown, again with good agreement. 
WAPD-TM-1443

\section{Flssion Gas Release Prom Oxide Fuels at High Burnups}

(AWBA Development Program)

C. C. Dollins

\section{Introduction}

When f18sion occurs, inert gas atoms are produced. In the design of reactors contalning rod-type fuel elements it 18 necessary to know how much of this gas is retalned in the fuel and how much excapes to the fuel rod plenum and the gap between the fuel and cladding. Gas whlch escapes from the fuel increases the temperature at which the fuel operates due to a decrease in thermal conductivity across the fuel-clad gap and increases the gas pressure inside the rod. These effects can potentially result in excessive clad strains during normal operation or unacceptable flow blockage due to clad rupture or clad ballooning in the case of a LOCA. Thus, 19 the amount of gas that escapes from the fuel is serlously underestimated, melted fuel and clad ruptures can potentially occur, resulting in unacceptable contamination in the primary coolant. If, on the other hand the amount of gas escaping the fuel 18 overestimated, then the fuel may not be used to its safe full potent1al.

The steady state swelling and gas release model recently developed ${ }^{(1)}$ has been modified to account for changes in temperature, temperature gradient, pressure, and fission rate with time. These were program changes and do not Involve changes to the theory.

The procedure to include the effect of changes in the variables during the fuel history is a straightforward modification of the previous procedure which did not permit such changes. Both programs operate on the basis of the effect of an increment in time. 
As an example the calculation of the migration of gas out of a grain of material involves the solution of a modified form of Fick's second 1aw. There is a spatial distribution of mesh points radially distributed within the graln. The concentration of gas at each mesh point is calculated at each time step. If the temperature is changed then the gas atom diffusion coefficient is changed and the calculation proceeds as in the previous time step. A change in fission rate results in a change il the diffusion icoefficient as explained in Refesence (1). A change in pressure would also result in an instantaneous change in the diffusion coefficient as stated in Reference (1). Calculations using the modified model have been compared to measurements of fission gas release for LMFBR rods whose data were obtained by Dutt and Baker ${ }^{(2)}$ and reported by Meyer et al ${ }^{(3)}$. The rods contained $\mathrm{vO}_{2}-25 \mathrm{w} / \mathrm{O} \mathrm{PuO}_{2}$ fuel with densities from $93 \%$ to $97 \% \mathrm{TD}$. The grain size was not quoted. The temperature and fission rate histuries for the rnds for which comparisons could be made were obtained from Meyer et al (4).

Theory

The gas release model previously described ${ }^{(1)}$ has been modified to accommodate changes in temperature, pressure, fission rale and tomperature gradieut with burnup.

The orfglual modal assumed that fission gas migrates to the grain faces either as isolated atnms or in bubbles. From the grain faces the gas was assumed to migrate to the intersection bulween three grains and from there to grain corners (the intersection of four grains). It was also assumed that the gas remained at the corners until the swelling due to gas at the corners and along the grain boundary edges reaches $5 \%$ of the total volume at: which time tunnels form venting the gas to the surface. It was assumed that once the tunnels formed they remained throughout life. 
Calculations using the model of Reference (1) 1ndicate that very little gas rematns at the grain boundsiry edges; consequently, in the modified version It is assumed that once the gas leaves the grain faces it goes directly to the grain corners.

The modlfied version also allows for the tunnels to pinch off once the gas escapes and for the resulting pores which formed from the tunnels to dissolve. This change is necessary to account, for the case where the fuel is taken from a high temperature (where it is easy for the tunnels to form) to a low temperature (where they would normally not form). Both models predict the same gas release under steady state conditions, as expected. This provides a cross check on the two calculation procedures.

\section{Data Comparisons}

Comparisons have been made between predictions made with the modified model and the Dutt and Baker data. The density, temperature, f1ssion rate and burnups for the Dutt and Baker data used in the analyois are shown in Table I. A grain size of 10 microns was assumed. Both the measured and predicted gas releases are given in the Table. Figure 1 is a plot of the predicted gas relesse versus the observed gas release for the Dutt and Baker data. The model is in generally good agreement with the data; hovever, in some cases too little gas is predicted to escape. Comparlsons vere also made between gas release predictions obtained by the model and gas release measurements made by $\mathrm{Zimmermann}(5)$ on $\mathrm{UO}_{2}-\mathrm{PuO}_{2}$ fuels. Zimmermann divided his specimens Into three groups depending on the final average fuel temperiture. Zimermann's specimens cooled during operation. Maximum temperatures for Zimmermann's specimens were obtalned from the quoted power levels and conductivity data reported by Babcock and W1Icox ${ }^{(6)}$. The conductivity was modifled for the Inclusion of $\mathrm{PuO}_{2}$ in the $\mathrm{UO}_{2}$ and for the low density (88\%) of the Zlamemann 
specimens using techniques described by 01 ander ${ }^{(7)}$. The temperatures calculated using the maximum power conditions were averaged with the cooler end of life temperatures given by Zimmerman. A grain size of $10 \mu_{m}$ was assumed for Zimmermann's specimens. The predictions (solid curve) for the specimens with end of 1 ife mean temperature of $1000^{\circ} \mathrm{C}$ are shown in Figure 2 along with Zimmermann's measurements. The 1250 and $1500^{\circ} \mathrm{C}$ curves are shown in Figures 3 and 4 respectively. Comparisons between the gas release predlotod by the Bettis unmodified morel, which gives the same gas release as the modified model for fuel operated under constant conditions, and data obtained hy Lewis ${ }^{(8)}$ and Hilbert et al ${ }^{(9)}$ were made in the previous work ${ }^{(1)}$. Figure 5 is a plot of the predicted gas release versus observed gas release for the three sets of data from References (5), (8) and (9). Lewis' fuel was $\mathrm{UO}_{2}$ with an initial density above $96 \%$-TD. No grain s1ze was given. The data of Hilbert et al were obtained on $\mathrm{UO}_{2}$ with densities of 90 or $97 \% \mathrm{TD}$. The grain sizes varied from 10 to $50 \mu \mathrm{m}$.

\section{Discussion}

Figure 6 is a plot of gas release versus burnup for burnups greater than 20,000 Md/t. The solid curves are the predictione for the author's model ${ }^{(1)}$. The curves were obtained at fixed temperatures. The bottom curve io for $11 \mathrm{n}^{\circ} \mathrm{C}$ and the top curve for $1500^{\circ} \mathrm{C}$. The intermediate curves arc for varions specific temperatures between 1100 and $1500^{\circ} \mathrm{C}$.

'lhe Bettls model racugnirea that at low temperatures less gas is released even at high burnups as shown by the $1000^{\circ} \mathrm{C}$ volume average temperature results of Zimmermann which has about $70 \%$ gas release at burnups as high as 114,000 MWd/t, Figure 2. A $1000^{\circ} \mathrm{C}$ volume average temperature specimen has a large portion of the fuel operating at much higher temperatures. The gas release results in Figure 6 assume that the entire specimen is at one temperature. 
The Dutt and Baker data had an end of life average surface temperature of about $820^{\circ} \mathrm{C}$. Commercial LWR cores have end of life surface temperatures about $300^{\circ} \mathrm{C}$ cooler since water is used as a coolant rather than liquid metal. The fact that so much of the fuel in LWR's near the pellet surface is at a much cooler temperature than in LMFBR's (Dutt and Baker) means that a good portion of the fuel would have gas release below the bottom curve of Figure 6 . This will tend to keep the overall gas release in LWR's lower than for LMFBR fuel. For example, the Bettis model predicts $64 \%$ release from $\mathrm{UO}_{2}$ operated to a burnup of $100,000 \mathrm{MWd} / \mathrm{t}$ at a surface temperature of $538^{\circ} \mathrm{C}\left(1000^{\circ} \mathrm{F}\right)$ and a center temperature of $2204^{\circ} \mathrm{C}\left(4000^{\circ} \mathrm{F}\right)$. Knowledge of gas release at high burnups can have a big impact on designs with higher burnups, for example the annuli of EPRI dual region fuel pellets ${ }^{(10)}$.

\section{Conclusions}

The Bettis model for gas release agrees well with data obtained by Hilbert et al and Lewis at low burnups and with the data of Dutt and Baker obtained at high burnups and high temperatures. The model also agrees well with the low temperature and high burnup data obtained by Zimmermann. The model will be compared to other data as they become available. 


\section{References}

(1) C. C. Dollins and F. A. N1chols, "Swelling and Gas Release in $\mathrm{UO}_{2}$ at Low and Intermediate Temperatures", J. Nucl. Mater., 66, 143 (1977).

(2) D. S. Dutt and R. B. Baker, "SIEX A Correlated Code for the Prediction of Ifquid Metal Fast Breeder Reactor (IMPBR) Fuel Thermal Performance", HEDL-TME 74-55, 1975.

(3) R. O. Meyer, C. E. Beyer, and J. C. Voglewede, "F1ssion Gas Release from Fuel at H1gh Burnup", Nuclear Safety, 19, 699 (1978).

(4) R. O. Meyer, C. B. Beyer, and J. C. Voglewede, "Pission Gas Release From Fuel at H1gh Burnup," NURBG-0418, March 1978.

(5) H. Zimmermann, "Flssion Gas Behavior in Oxide Fuel Elements of Fast Breeder Reacturs", Nual. Tech. 20, 127 (1976).

(6) "Babcook and Wilcox Standard Muclear Steam System (B-SAR-205, Vol I)", February 27, 1976, DOCKLIT-STN-50-561.

(7) D. R. Olander, "Fundamental Aspects of Nuclear Reactor Fuel Elements", ERDA, 1976.

(8) W. B. Lewis, "Engineering for the Flssion Gas in. $\mathrm{UO}_{2}$ Fuel", Nucl. Appl. 2 , $171(1966)$.

(9) R. F. Hilbert, V. W. Storhok, W. Chubb, and D. L. Keller, "Mechan1sms of Swelling and Gas Releuse in Uranium Dioxide", J. Nucl. Mater., 38, 26 (1971).

(10) A. Roberts and H. Ocken, "Improving Nuclear Fuel Rellab1l1ty", BPRI Journal, Vol. 3, No. 8, p. 75 (1978). 


\section{TABLE I}

\begin{tabular}{|c|c|c|c|c|c|c|c|}
\hline \multirow[b]{2}{*}{$\begin{array}{c}\text { Specimen } \\
\text { Number } \\
\end{array}$} & \multirow[b]{2}{*}{$\begin{array}{c}\text { Density } \\
\text { \& TD }\end{array}$} & \multirow{2}{*}{$\begin{array}{c}\text { Fission Rate } \\
\mathrm{f} / \mathrm{cm}^{3} \text { sec } \\
\left(\times 10^{13}\right) \\
\end{array}$} & \multirow{2}{*}{$\begin{array}{l}\text { Burnup } \\
\text { f/cm3 } \\
\left(x 10^{20}\right) \\
\end{array}$} & \multicolumn{2}{|c|}{ Temperature $\left({ }^{\circ} \mathrm{C}\right)$} & \multirow[b]{2}{*}{$\begin{array}{c}\text { Measured Gas } \\
\text { Release } \text { o }^{2} \\
\end{array}$} & \multirow[b]{2}{*}{$\begin{array}{c}\text { Predicted Gas } \\
\text { Release } \% \\
\end{array}$} \\
\hline & & & & Surface & Center & & \\
\hline PNL 3-20 & 96.2 & 2.7 & $\begin{array}{l}6.6 \\
8.8 \\
12\end{array}$ & $\begin{array}{l}670 \\
790 \\
930\end{array}$ & $\begin{array}{l}1000 \\
1180 \\
1360\end{array}$ & 39.1 & 24.4 \\
\hline PNL 3-23 & 95.9 & 2.8 & $\begin{array}{l}6.7 \\
7.3\end{array}$ & $\begin{array}{l}666 \\
694\end{array}$ & $\begin{array}{l}962 \\
1016\end{array}$ & 1.8 & 1.1 \\
\hline PNL 4-1 & 94.6 & 5.1 & $\begin{array}{r}1.9 \\
3.9 \\
5.8 \\
7.7 \\
11.2\end{array}$ & $\begin{array}{l}770 \\
735 \\
750 \\
790 \\
845\end{array}$ & $\begin{array}{l}1700 \\
1640 \\
1645 \\
1700 \\
1760\end{array}$ & 62.2 & 55.8 \\
\hline PNL $4-20$ & 93.6 & 4.13 & $\begin{array}{l}1.9 \\
5.7 \\
7.6 \\
9.5 \\
11 .\end{array}$ & $\begin{array}{l}760 \\
725 \\
780 \\
850 \\
880\end{array}$ & $\begin{array}{l}1450 \\
1390 \\
1460 \\
1550 \\
1570\end{array}$ & 63.8 & 41.9 \\
\hline PNL 4-26 & 97. & 4.8 & $\begin{array}{l}1.9 \\
5.7 \\
7.6 \\
9.5 \\
11 .\end{array}$ & $\begin{array}{l}770 \\
750 \\
790 \\
830 \\
840\end{array}$ & $\begin{array}{l}1700 \\
1680 \\
1720 \\
1765 \\
1770\end{array}$ & 64.5 & 56.2 \\
\hline PNL $4-34$ & $95 \cdot 3$ & 4.6 & $\begin{array}{r}1.8 \\
5.5 \\
7.4 \\
9.2 \\
10.7\end{array}$ & $\begin{array}{l}815 \\
815 \\
855 \\
940 \\
965\end{array}$ & $\begin{array}{l}1705 \\
1705 \\
1745 \\
1835 \\
1855\end{array}$ & 65.4 & 66.5 \\
\hline PNL 7-10 & 95.2 & 5. & 6.6 & 850 & 1710 & 30.1 & 51.3 \\
\hline
\end{tabular}

Parameters Used in Making Comparisons with the Dutt and Baker Data 
TABLE I (Continlied!

\begin{tabular}{|c|c|c|c|c|c|c|c|}
\hline \multirow[b]{2}{*}{$\begin{array}{l}\text { Specimen } \\
\text { Number }\end{array}$} & \multirow[b]{2}{*}{$\begin{array}{l}\text { Density } \\
\text { of TD } \\
\end{array}$} & \multirow{2}{*}{$\begin{array}{c}\text { Fissign Rate } \\
f / \mathrm{cm}^{3} \mathrm{ecc} \\
\left(\mathrm{xl} 0^{13}\right) \\
\end{array}$} & \multirow{2}{*}{$\begin{array}{l}\text { Burnup } \\
\mathrm{f} / \mathrm{cm} 3 \\
\left(x 10^{20}\right) \\
\end{array}$} & \multicolumn{2}{|c|}{ Temperature $\left({ }^{\circ} \mathrm{C}\right)$} & \multirow[b]{2}{*}{$\begin{array}{c}\text { Measured Gas } \\
\text { Release } \$ \\
\end{array}$} & \multirow[b]{2}{*}{$\begin{array}{c}\text { Predicted Gas } \\
\text { Release } \varnothing\end{array}$} \\
\hline & & & & Surface & Center & & \\
\hline PNL 8-11 & 93.5 & 6.9 & $\begin{array}{r}2.5 \\
7.6 \\
10.2 \\
12.7 \\
15\end{array}$ & $\begin{array}{l}830 \\
770 \\
870 \\
870 \\
870\end{array}$ & $\begin{array}{l}1960 \\
1900 \\
2120 \\
2110 \\
2090\end{array}$ & 92.2 & 70.6 \\
\hline PNL 8-25 & 93.8 & 6.8 & $\begin{array}{r}2.6 \\
7.7 \\
10.2 \\
12.8 \\
14.8\end{array}$ & $\begin{array}{l}810 \\
790 \\
850 \\
850 \\
850\end{array}$ & $\begin{array}{l}1980 \\
1920 \\
26: 30 \\
2020 \\
2010\end{array}$ & 94.3 & 67.6 \\
\hline PNL 8-..8 & 93.9 & 5.5 & $\begin{array}{c}2.5 \\
5 . \\
7.5 \\
14.6\end{array}$ & $\begin{array}{l}770 \\
740 \\
800 \\
820\end{array}$ & $\begin{array}{l}1980 \\
1920 \\
1990 \\
1370\end{array}$ & 62.6 & 61.8 \\
\hline PNL $8-37$ & 93.6 & 6.6 & $\begin{array}{r}7.4 \\
14.3\end{array}$ & $\begin{array}{l}770 \\
820\end{array}$ & $\begin{array}{l}1910 \\
1890\end{array}$ & 65.2 & 61.9 \\
\hline PNL $8-38$ & N.A. & 6.7 & 7.4 & 770 & 1900 & 53.6 & 55.9 \\
\hline PNL 9-30 & N.A. & 3. & $\begin{array}{c}3 \\
6 \\
9.1 \\
12.7\end{array}$ & $\begin{array}{l}760 \\
710 \\
760 \\
930\end{array}$ & $\begin{array}{l}1380 \\
1320 \\
1400 \\
1640\end{array}$ & 53:8 & 56.6 \\
\hline PNL 10-23 & $\mathbf{N} \boldsymbol{\alpha}$. & 4.8 & $\begin{array}{r}2.3 \\
6.8 \\
13.1\end{array}$ & $\begin{array}{l}860 \\
850 \\
890\end{array}$ & $\begin{array}{l}1840 \\
1790 \\
1840\end{array}$ & 67.5 & 65.1 \\
\hline PNL $10-63$ & N.A. & 4.9 & 13.6 & 840 & 1825 & 71.5 & 62 \\
\hline
\end{tabular}


TABLE I (Continued)

\begin{tabular}{|c|c|c|c|c|c|c|c|}
\hline \multirow{2}{*}{$\begin{array}{c}\text { Specimen } \\
\text { Number }\end{array}$} & \multirow{2}{*}{$\begin{array}{l}\text { Density } \\
\text { of TD }\end{array}$} & \multirow{2}{*}{$\begin{array}{l}\text { Fission Rate } \\
\text { 1/ } \mathrm{cm}^{3}{ }^{13 e c} \\
\left(x_{1} 0^{13}\right) \\
\end{array}$} & \multirow{2}{*}{$\begin{array}{l}\text { Burnup } \\
\mathrm{f} / \mathrm{cm}^{3} \\
\left(\mathrm{xl0} 0^{20}\right) \\
\end{array}$} & \multicolumn{2}{|c|}{ Temperature $\left({ }^{\circ} \mathrm{C}\right)$} & \multirow{2}{*}{$\begin{array}{c}\text { Measured Gas } \\
\text { Release } \% \\
\end{array}$} & \multirow{2}{*}{$\begin{array}{l}\text { Predicted Gas } \\
\text { Release } \% \\
\end{array}$} \\
\hline & & & & Surface & Center & & \\
\hline PNL $17-6$ & N.A. & 5.4 & $\begin{array}{l}0.9 \\
5.1 \\
8.4\end{array}$ & $\begin{array}{l}965 \\
900 \\
880\end{array}$ & $\begin{array}{l}1860 \\
1770 \\
1950\end{array}$ & 58.1 & 64.5 \\
\hline PNL 17A-5 & N.A. & 6.7 & $\begin{array}{l}0.25 \\
0.5 \\
0.75 \\
0.9\end{array}$ & $\begin{array}{r}1000 \\
930= \\
870 \\
820\end{array}$ & $\begin{array}{l}2190 \\
2110 \\
2030 \\
1960\end{array}$ & 32.6 & 49.4 \\
\hline
\end{tabular}




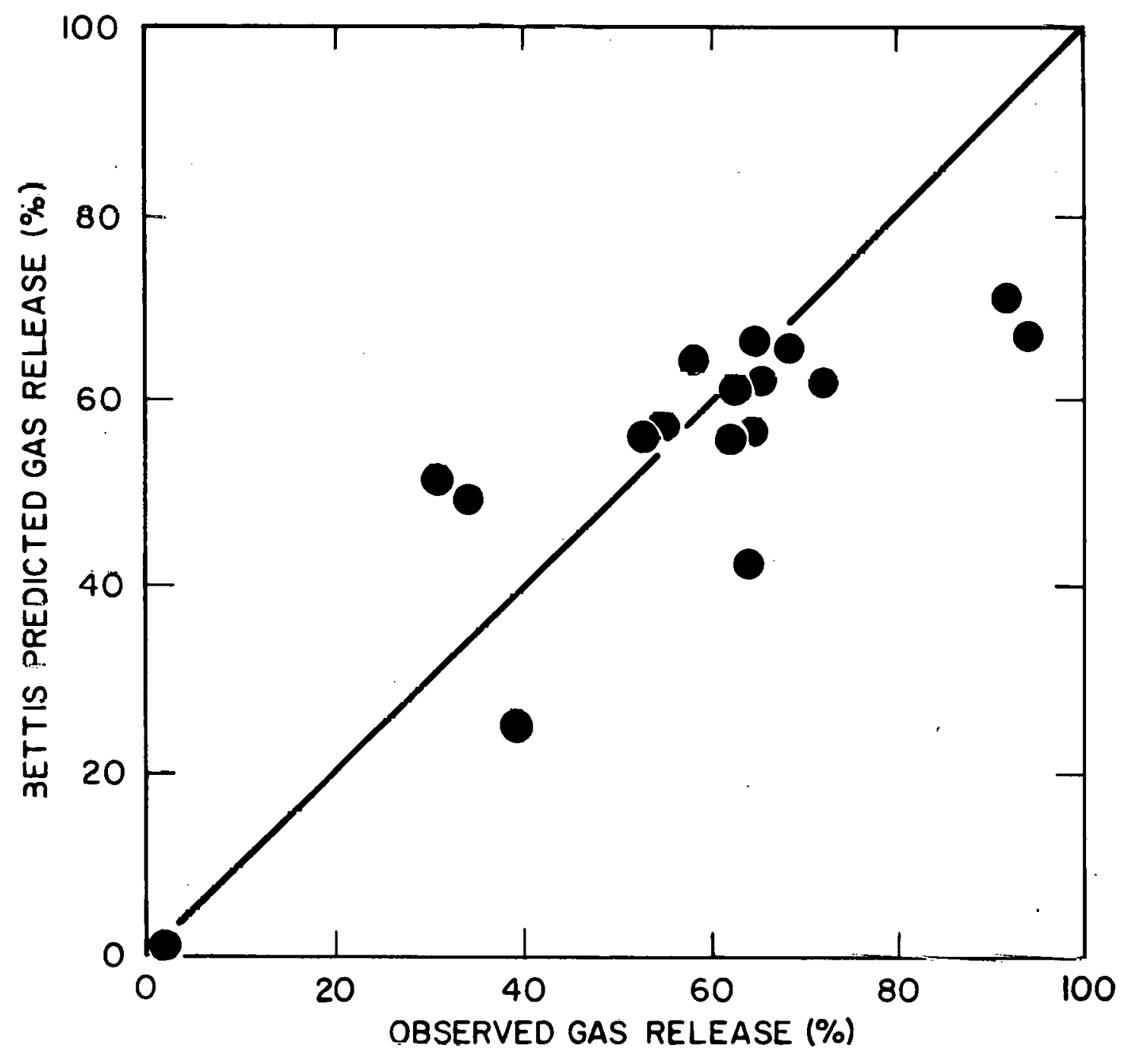

FIGURE ।

Comparlsans between the jo a release predictione of the 3ettis model and the reasured results of thit and saker. 


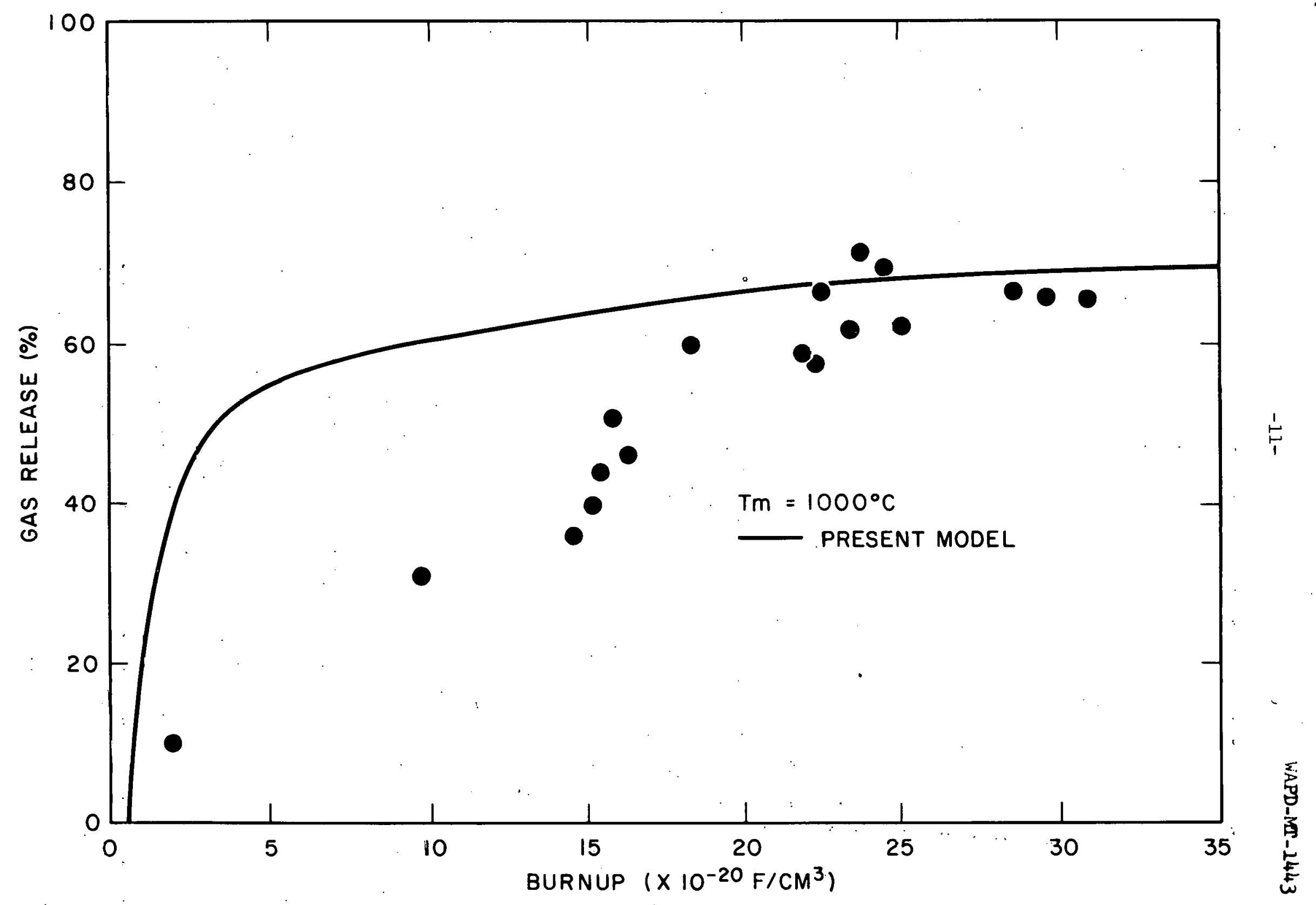

FIGURE 2. COMPARISON BETWEEN THE MODEL PREDICTIONS, AND ZIMMERMAN'S DATA WITH END OF LIFE MEAN TEMPERATURE OF $1000^{\circ} \mathrm{C}$ 


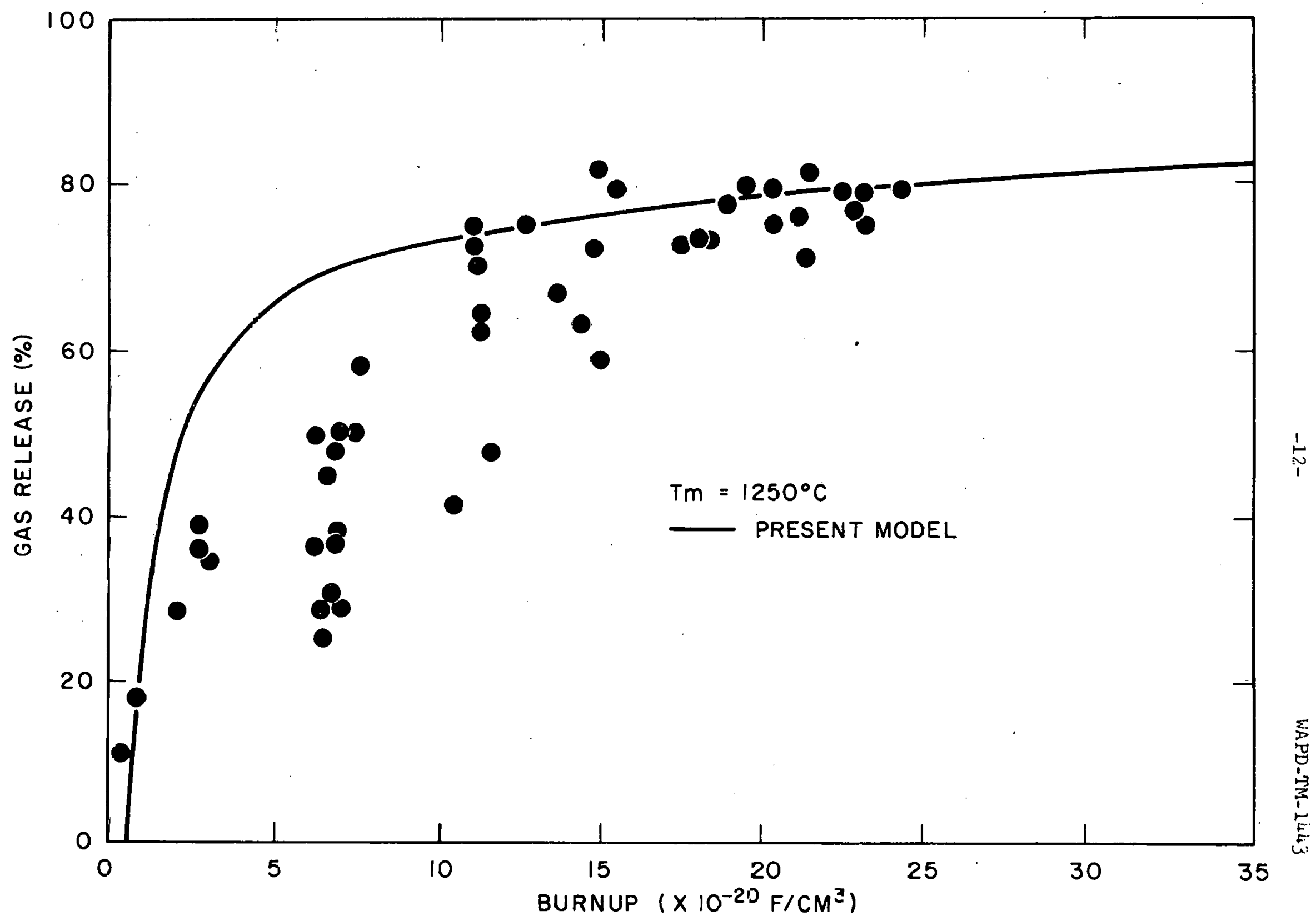

FIGURE 3. COMPARISON BETWEEN THE MODEL PREDICTIONS, AND ZIMMERMAN'S DATA WITH END OF LIFE MEAN TEMPERATURE OF $1250^{\circ} \mathrm{C}$ 


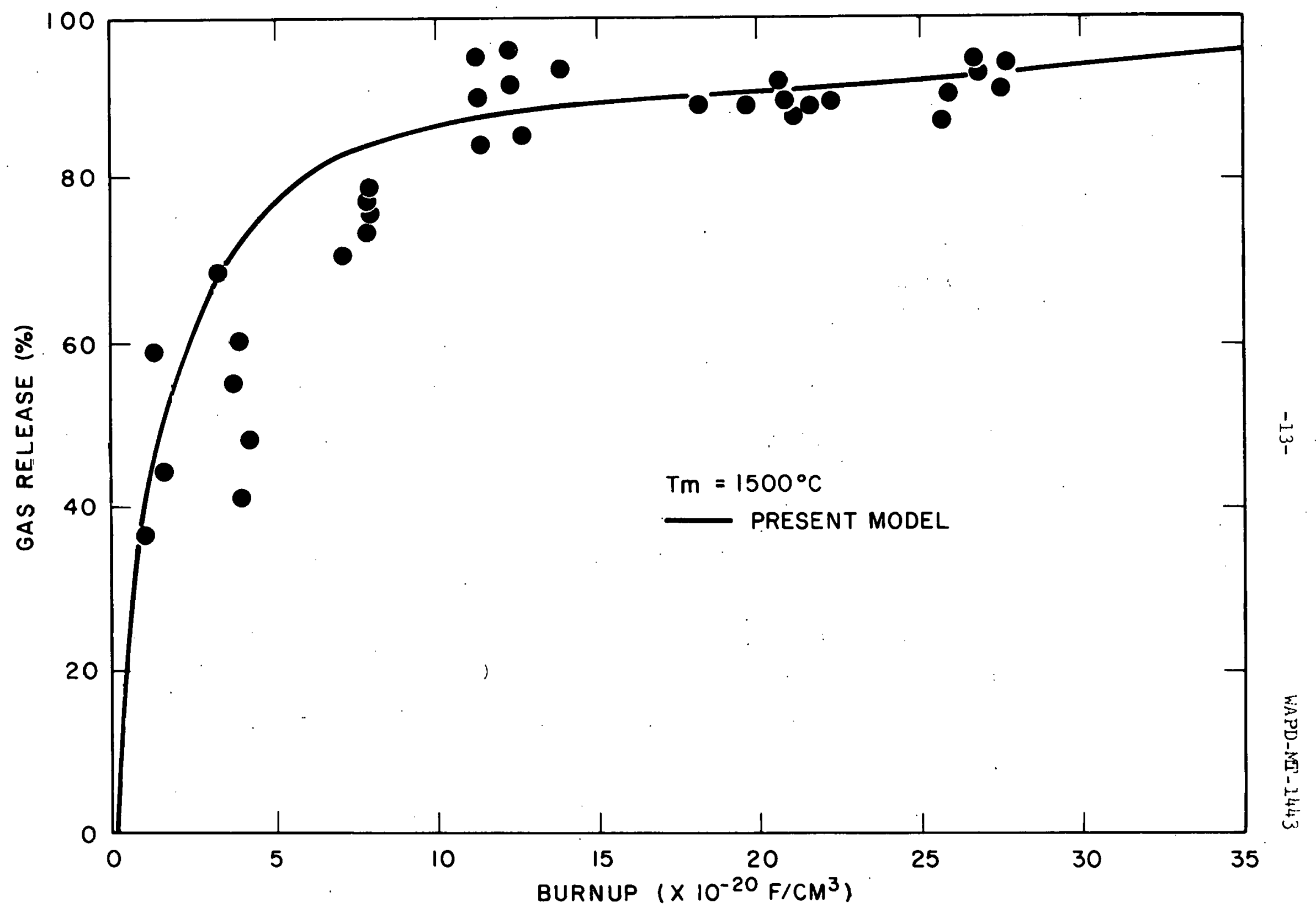

FIGURE 4 COMPARISON BETWEEN THE MODEL PREDICTIONS, AND ZIMMERMAN'S DATA WITH END OF LIFE MEAN. TEMPERATURE OF $1500^{\circ} \mathrm{C}$ 


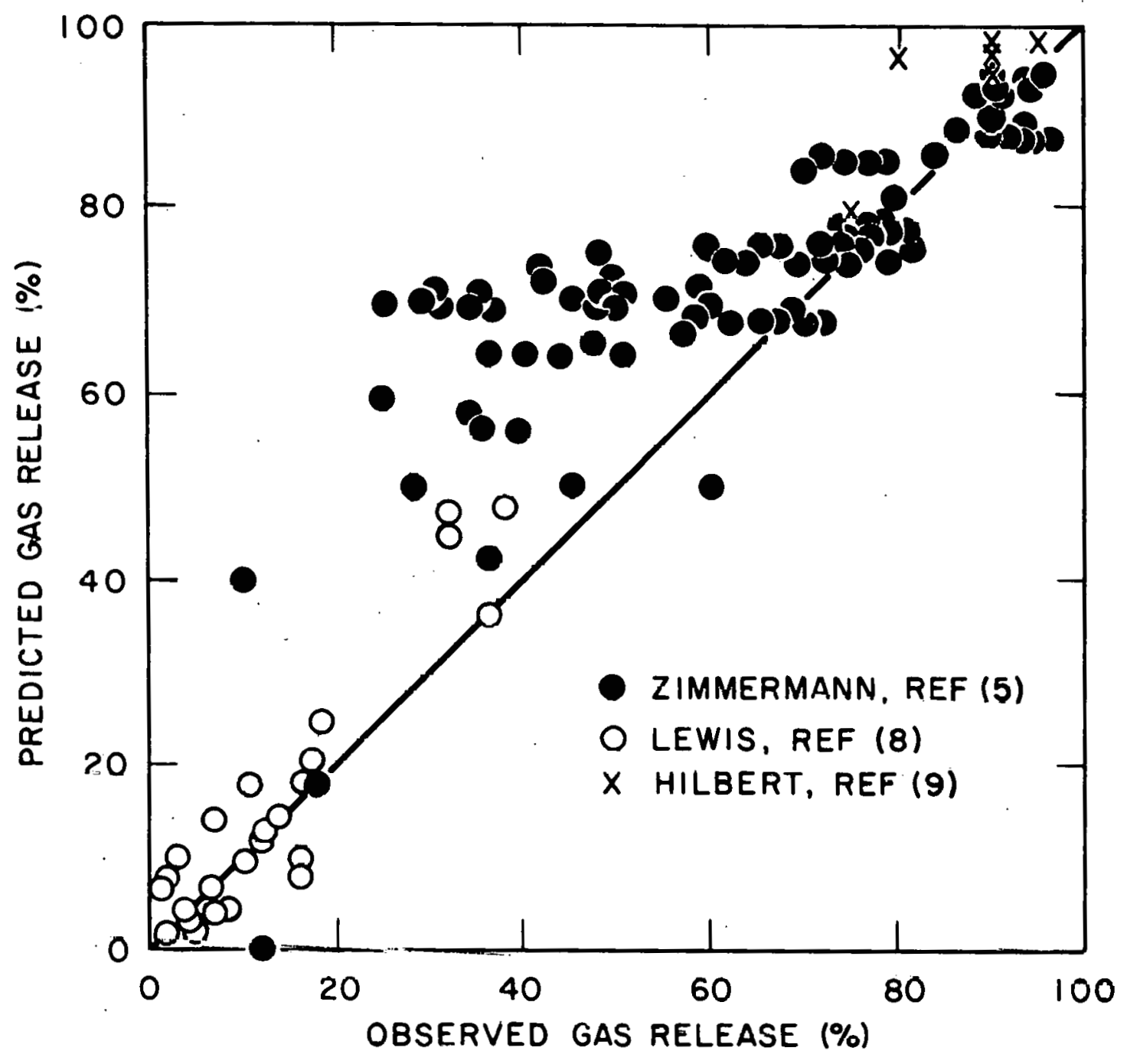

Figure 5

Comparisor between the gas release predlctions of the Bettis model and the measured results from References (5), (8), and (9). 


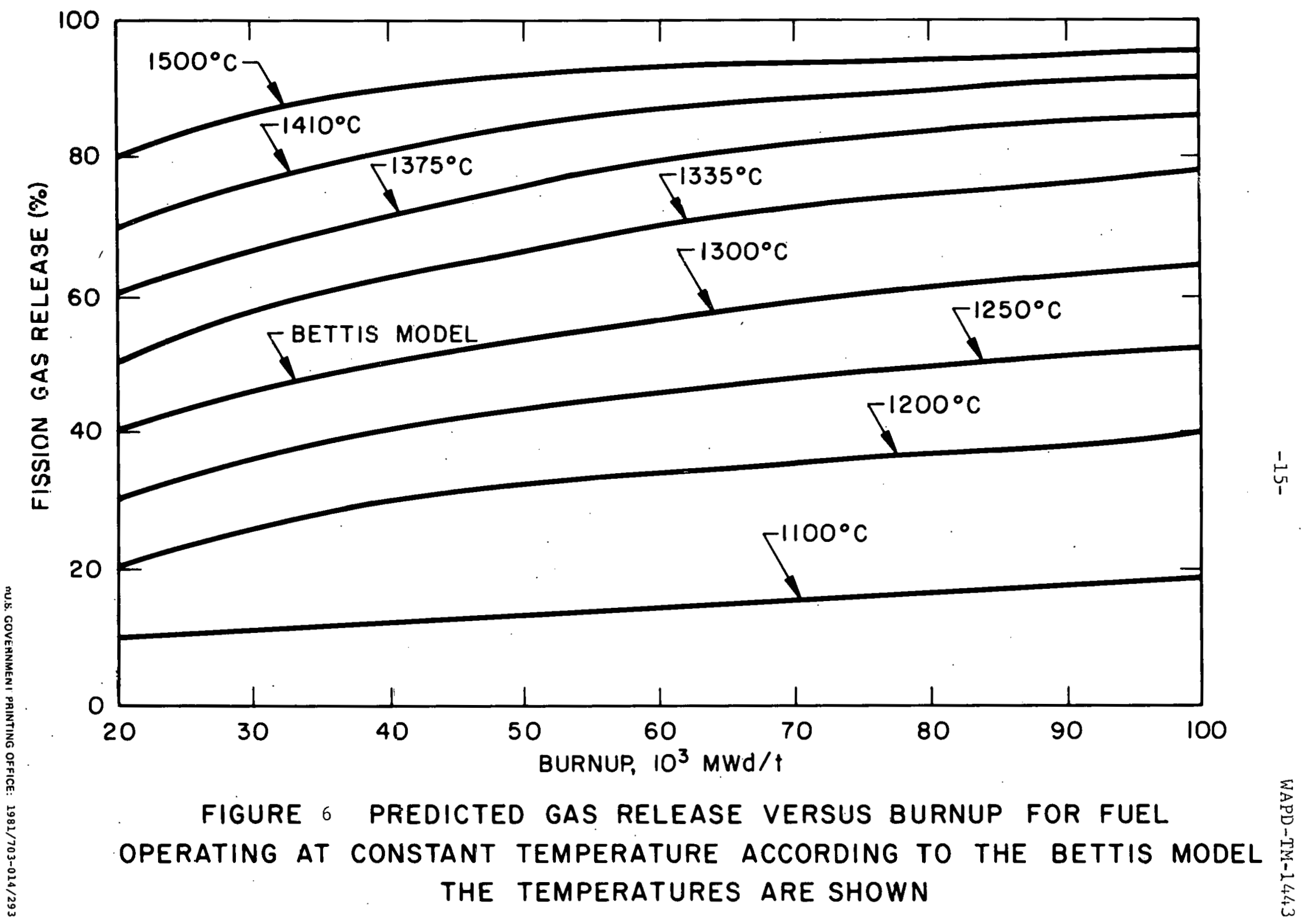

